\title{
Comparing trace element concentrations in muscle tissue of marbled eel Anguilla marmorata reared in three different aquaculture systems
}

\author{
Li Li ${ }^{1, *}$, Wenjing Ren ${ }^{1}$, Chengyue Liu ${ }^{1}$, Shuanglin Dong ${ }^{1}$, Yunhao Zhu ${ }^{2}$ \\ ${ }^{1}$ Key Laboratory of Mariculture, Ministry of Education, Ocean University of China, Qingdao 266003, PR China \\ ${ }^{2}$ College of Fishery \& Life Science, Shanghai Ocean University, Shanghai 201306, PR China
}

\begin{abstract}
There is a growing trend towards culturing fish in intensive recirculating aquaculture systems, which have a reduced need for water exchange compared to many other systems. However, it is unknown whether these intensive aquaculture operations facilitate bioaccumulation of trace elements in fish tissue. The present study therefore evaluated and compared the accumulation of 20 trace elements in the flesh of marbled eel Anguilla marmorata reared in 3 different systems: a recirculating aquaculture system (RAS), a biofloc technology system (BFT), and a concrete pond ( $\mathrm{CP}$; traditional method). In the BFT system fish were also raised in polyculture with tilapia Oreochromis niloticus and water spinach Ipomoea aquatica Forsk. Fish were fed the same feed and reared in water from the same source. The trace elements $(\mathrm{Al}, \mathrm{As}, \mathrm{Ba}, \mathrm{Be}, \mathrm{Co}, \mathrm{Cr}$, $\mathrm{Cu}, \mathrm{Fe}, \mathrm{Li}, \mathrm{Mn}, \mathrm{Mo}, \mathrm{Ni}, \mathrm{Pb}, \mathrm{Sb}, \mathrm{Se}, \mathrm{Sn}, \mathrm{Sr}, \mathrm{Ti}, \mathrm{V}$, and $\mathrm{Zn}$ ) in the fish flesh were analyzed by inductively coupled plasma-optical emission spectrometry. Fish reared in the RAS had elevated concentrations of only a single element (Al) compared with $\mathrm{CP}$ fish. This element was also elevated in $\mathrm{BFT}$ fish and was probably related to the high $\mathrm{Al}$ concentration in the fish feed. Fish reared in the BFT system also showed significantly higher levels of $\mathrm{As}, \mathrm{Ba}, \mathrm{Cr}, \mathrm{Fe}, \mathrm{Mn}, \mathrm{Ni}, \mathrm{Se}, \mathrm{Sn}, \mathrm{Sr}, \mathrm{Ti}$, and $\mathrm{Zn}$ compared to both CP and RAS fish. The observed levels of (1) As in fish from BFT systems and (2) $\mathrm{Pb}$ in fish from both RAS and BFT systems exceeded national and international legislatory limits. Our results suggest that regular monitoring of trace element concentrations in BFT and RAS should be implemented in the future for this species.
\end{abstract}

KEY WORDS: Trace elements $\cdot$ Marbled eel $\cdot$ Anguilla marmorata $\cdot$ Recirculating aquaculture system $\cdot$ Biofloc system

\section{INTRODUCTION}

Interest in culturing fish in recirculating aquaculture systems (RAS) has been increasing recently, as using RAS could greatly reduce the need for water, land, and energy and lessen the release of nutrients from aquaculture operations to the environment (Martins et al. 2011) when compared with e.g. pond culture. In recirculating systems, the daily water exchange rate is reduced 30 to 50 times compared to that of an open system. Moreover, RAS can be close

${ }^{*}$ Corresponding author: 86lily@163.com to a closed system, with less than $10 \%$ daily water exchange (Deviller et al. 2005). Therefore, dissolved substances such as heavy metals, which are not removed by water treatments in RAS, will accumulate in the water of the system to such levels that they can be toxic to the fish (Deviller et al. 2005). Growth retardation, embryonic and larval development impairment and other sub-lethal effects have been observed in many fish species cultured in RAS with low water exchange rates (Davidson et al. 2009, 2011, Martins et al. 2009). Furthermore, there is a

() The authors 2018. Open Access under Creative Commons by Attribution Licence. Use, distribution and reproduction are unrestricted. Authors and original publication must be credited. 
possibility of metal accumulations in the edible tissues of cultured fish (Martins et al. 2011).

Biofloc technology (BFT) is a new technology used in aquaculture to allow the effective removal of nutrients while simultaneously producing beneficial microbial biomass under controlled conditions (Crab et al. 2007). This technology is largely used in shrimp and fish culture because it results in e.g. high production yields, feed protein recycling, better water quality, and bacterial infection control (Avnimelech \& Kochba 2009, Luo et al. 2014, Bakar et al. 2015). In the BFT system, the water is not changed and carbohydrates are usually added to the system to produce flocs, which provide a food source for fish. BFT can also be combined with polyculture technology to further enhance water quality within the rearing system (Crab et al. 2012). To our knowledge, the trace element concentrations in fish cultured in a biofloc system and in fish cultured by traditional methods such as concrete ponds (CPs) have not been compared.

Anguillid eels have high nutritional value and are one of the most important commercial species in China. Because the glass eels of Anguilla marmorata are easier to obtain and sold at a lower price than other eel species, cultivation of A. marmorata has increased in southeastern China in recent years (Luo et al. 2013). A. marmorata are cultured in both extensive and intensive systems and are highly suitable for recirculating aquaculture systems, allowing for a less water-intensive and thus more sustainable and environmentally friendly production.

The present study aimed to compare the concentrations of 20 trace elements in A. marmorata cultured in 3 different systems (RAS, BFT, and CP). We hypothesized that any differences in trace element accumulation would be mostly due to the culture method. The primary objectives of the study were: (1) to determine if marbled eel reared in highly closed RAS tanks have higher trace element levels than those reared in CPs and (2) to determine if eels reared in BFT systems have different trace element levels compared with those reared in RAS or CPs.

\section{MATERIALS AND METHODS}

We obtained 7500 eels (mean weight about $50 \mathrm{~g}$ ) from Jixiang Marbled Eel Fisheries Company (Fujian, China). The fish were acclimated for $2 \mathrm{wk}$ in 4 cone fiberglass tanks (working volume $1.0 \mathrm{~m}^{3}$, 500 eels per tank) or 18 rectangular concrete ponds $(5 \times 3 \times 1.2 \mathrm{~m}, 300-400$ eels per pond) located in cement houses at the Binhai research station of
Shanghai Ocean University (Shanghai, China). During the acclimation period, the fish were fed to satiation twice daily (at 6:00 and 18:00 h) with a commercial feed (moisture $\leq 10 \%$; crude protein $\geq 48.0 \%$; crude fat $\geq 4.0 \%$ and ash $\leq 17.0 \%$ ) produced by the Gaonong Feed Company (Fujian, China). The water source for this study was the Dazhi River, which is located in Binhai Town of PuDong New District, Shanghai, China. The river water was precipitated in a sedimentation tank and filtered by a sand filter to remove big particles before usage. One-third to onehalf of the water in the acclimation tanks or ponds was replaced daily to ensure good water quality. Dissolved oxygen was maintained above $5 \mathrm{mg} \mathrm{l}^{-1}, \mathrm{pH}$ ranged from 7.0 to 8.0 , temperature ranged from 24 to $25^{\circ} \mathrm{C}$, and a natural photoperiod was applied.

After acclimation, fish were haphazardly assigned to the 3 production systems: concrete ponds $(5 \times 3 \times$ $1.2 \mathrm{~m}, 100$ eels per pond), biofloc ponds $(5 \times 3 \times 1.2 \mathrm{~m}$, 100 eels per pond) and RAS tanks (working volume $1.0 \mathrm{~m}^{3}, 200$ eels per tank) with 3 replicates for each system. The numbers of fish stocked in RAS were higher than the other 2 rearing systems because RAS is generally more intensive than traditional pond culture. This difference in initial stocking number did not impact the growth performance of the fish (see 'Results' and 'Discussion'). CPs consisted of a monoculture of Anguilla marmorata with one third of the water being exchanged every $10 \mathrm{~d}$. BFTs consisted of a polyculture of eels, tilapia Oreochromis niloticus (average weight $75 \mathrm{~g}, 16$ fish per tank) and water spinach Ipomoea aquatica Forsk without any water exchange but with production of bioflocs. The RAS tanks contained a monoculture of eels and was a nearly closed system (less than $10 \%$ of water was exchanged daily to supplement the water loss from evaporation and back wash of the drum filter). The feeding regime was the same as during acclimation.

After $70 \mathrm{~d}, 5$ fish were collected haphazardly from each pond or tank ( $\mathrm{n}=15$ per system), weighed and their length measured (Table 1). The sampled fish exhibited no significant difference in weight or length

Table 1. Mean $( \pm \mathrm{SE})$ weight and length of Anguilla marmorata collected from 3 culture systems (RAS: recirculating aquaculture system; BFT: biofloc technology; CP: concrete ponds)

\begin{tabular}{|lcc|}
\hline System & Weight $(\mathrm{g})$ & Length $(\mathrm{cm})$ \\
\hline RAS & $157.07 \pm 7.25$ & $39.13 \pm 0.66$ \\
BFT & $176.20 \pm 7.97$ & $40.36 \pm 0.57$ \\
CP & $165.73 \pm 4.81$ & $39.90 \pm 0.43$ \\
\hline
\end{tabular}


among groups (ANOVA, $\mathrm{p} \geq 0.05$ ), which eliminated the effect of fish size on trace element concentration in fish tissues.

The fish were sacrificed by a blow to the head, eviscerated, skinned, filleted, and trimmed manually with a ceramic knife to obtain the dorsal muscle. The muscle from each fish was washed with distilled water and stored at $-70^{\circ} \mathrm{C}$. The frozen samples were freeze-dried to a constant weight. Afterwards, samples were homogenized using a grinder and stored in desiccators until further analysis.

All fish samples were analyzed by the Instrumental Analysis Center at Shanghai Jiao Tong University (Shanghai, China). The samples were digested following the protocol by Lee et al. (2006). Briefly, $0.5 \mathrm{~g}$ of fish sample was digested in nitric acid and perchloric acid (4:1 vol:vol). Subsequently, samples were subjected to elemental analysis by inductively coupled plasma-optical emission spectrometry (iCAP 6300, Thermo Fisher Scientific) for 20 elements: aluminum (Al), arsenic (As), barium (Ba), beryllium (Be), cobalt $(\mathrm{Co})$, chromium $(\mathrm{Cr})$, copper $(\mathrm{Cu})$, iron $(\mathrm{Fe})$, lithium (Li), manganese (Mn), molybdenum (Mo), nickel $(\mathrm{Ni})$, lead $(\mathrm{Pb})$, antimony $(\mathrm{Sb})$, selenium $(\mathrm{Se})$, tin $(\mathrm{Sn})$, strontium $(\mathrm{Sr})$, titanium $(\mathrm{Ti})$, vanadium $(\mathrm{V})$, and zinc (Zn). The results are shown as $\mu \mathrm{g} \mathrm{g}^{-1}$ of dry weight. Except for the metalloids $\mathrm{As}, \mathrm{Sb}$, and $\mathrm{Se}$, these elements are all metals.

All glassware used during the analysis was soaked in diluted $\mathrm{HNO}_{3}$ solution (5-10\%) for $48 \mathrm{~h}$ and rinsed 4 times with deionized water prior to use. A procedural blank was run after each batch of 12 samples, and measurements of blanks were subtracted from sample values. The accuracy of the trace element measurements was assessed using certified reference material of oyster tissue (1566a, National Institute of Standards and Technology, Gaithersburg, $\mathrm{MD}, \mathrm{USA}$ ), and the recovery of the trace elements ranged between 90 and $112 \%$.

Statistical analyses were performed using SPSS v17.0 (IBM). Differences in length and weight of marbled eels and in the trace element concentrations among fish from the 3 culture systems were assessed using 1-way ANOVA followed by a Duncan's multiple comparison test if a significant difference $(p<0.05)$ was detected. Normality of the data was checked using the Kolmogorov-Smirnov test. Homogeneity of variances was assessed using Levene's test. A non-parametric Kruskall-Wallis test and its post hoc test (Wilcoxon rank sum test) were used for $\mathrm{Be}, \mathrm{Fe}, \mathrm{Mn}, \mathrm{Sn}, \mathrm{Sr}, \mathrm{Ti}$, and $\mathrm{Zn}$ since data did not fit the parametric assumptions of normality and homogeneity of variances. Results are given as mean \pm SE.

\section{RESULTS AND DISCUSSION}

\section{Difference of trace elemental levels in Anguilla marmorata from the three culture systems}

As stated earlier, the sampled fish exhibited no significant difference in weight or length among groups (ANOVA, $p \geq 0.05$ ), which eliminated the effect of fish size on trace element concentration in fish tissues (see Table 1). As a promising new technology, the BFT has been successfully used to culture fish such as African catfish (Clarias gariepinus) and tilapia (Oreochromis niloticus). In a BFT system, water is usually not changed (Luo et al. 2014, Bakar et al. 2015), creating the risk of bioaccumulation of dissolved substances (Deviller et al. 2005). This can be offset by utilizing polyculture to improve water quality (Crab et al. 2012), as the nutrients in the BFT systems could be more efficiently used by several species with different feeding niches (Rahman et al. 2008). However, in fish from the BFT system, we found significantly higher concentrations of 11 elements (As, Ba, Cr, Fe, Mn, Ni, $\mathrm{Se}, \mathrm{Sn}, \mathrm{Sr}, \mathrm{Ti}$, and $\mathrm{Zn}$ ) (all ANOVAs: $\mathrm{p}<0.05$; Table 2). Among these elements, $\mathrm{As}, \mathrm{Ba}, \mathrm{Sn}$, and Ti are toxic trace elements, while the others are essential trace elements (Qin et al. 2015). The Fe concentration in fish

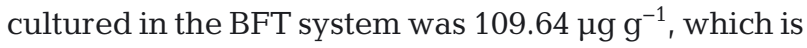
much higher than in fish reared in $\mathrm{CP}$ or RAS. Previous studies from Turkey also reported a wide range of Fe concentrations in fish, e.g. from 64.3 to $197 \mathrm{\mu g} \mathrm{g}^{-1}$ dry weight in 7 lake fish species (Mendil et al. 2005) or up to $167 \mu \mathrm{g} \mathrm{g}{ }^{-1}$ dry weight in 5 river fish species (Cyprinus carpio, Capoeta tinca, Leiciscus cephalus, Carassius gibelio, and Silurus glanis) sampled (Mendil \& Uluözlü 2007). By contrast, Fallah et al. (2011) reported low Fe levels (15.47 $\mu g^{-1}$ dry weight) in rainbow trout. We also found a significantly higher Zn concentration in BFT fish (77.01 $\mu \mathrm{g} \mathrm{g}^{-1}$ dry weight) than in the other 2 groups. By comparison, 5 species of fish (Oncorhynchus mykiss, Cyprinus carpio, Leiciscus cephalus, Capoeta tinca, and Chondrostoma regium) from a Turkish river had $\mathrm{Zn}$ concentrations from 11.6 to $63.5 \mathrm{\mu g} \mathrm{g}^{-1}$ dry weight (Mendil et al. 2010). The Ni concentration in fish from the BFT system in this study $\left(2.43 \mu \mathrm{g} \mathrm{g}^{-1}\right)$ was much higher than that in fish from the other 2 systems. Similar results were reported for Ni levels in different river fish species in Tokat, Turkey (1.1 to $10.2 \mu \mathrm{g} \mathrm{g}^{-1}$ dry weight; Mendil et al. 2010).

Only 1 element (Al) showed significantly higher concentration in fish reared in RAS than in fish from the traditional concrete ponds (ANOVA, $F_{2,42}=4.66$, $\mathrm{p}=0.02)$. Aluminum, categorized as non-essential 
Table 2. Mean $( \pm \mathrm{SE})$ concentration $\left(\mu \mathrm{g} \mathrm{g} \mathrm{g}^{-1}\right.$ dry weight) of 20 trace elements in the muscle of Anguilla marmorata after being reared for $70 \mathrm{~d}$ in one of 3 different systems (RAS: recirculating aquaculture system; BFT: biofloc technology; CP: concrete ponds). Different lower case letters among groups indicate that an element differed significantly (Duncan's test or Wilcoxon rank sum test, $\mathrm{p}<0.05$ ) among culture systems. Bold and italic: results from Kruskall-Wallis tests (H values) since data did not meet assumptions for parametric tests

\begin{tabular}{|lrcrrrr|}
\hline \multirow{2}{*}{ Element } & \multirow{2}{*}{$\mathrm{RAS}$} & \multirow{2}{*}{ BFT } & CP & For $H$ & df & \multicolumn{1}{c|}{$\mathrm{p}$} \\
\cline { 2 - 6 } & & & & & \\
$\mathrm{Al}$ & $19.36 \pm 2.42^{\mathrm{b}}$ & $20.39 \pm 2.57^{\mathrm{b}}$ & $12.14 \pm 0.74^{\mathrm{a}}$ & 4.66 & 2,42 & 0.02 \\
$\mathrm{As}$ & $1.18 \pm 0.09^{\mathrm{a}}$ & $2.06 \pm 0.08^{\mathrm{b}}$ & $1.36 \pm 0.08^{\mathrm{a}}$ & 32.92 & 2,42 & $<0.01$ \\
$\mathrm{Ba}$ & $1.02 \pm 0.11^{\mathrm{a}}$ & $1.54 \pm 0.15^{\mathrm{b}}$ & $0.76 \pm 0.03^{\mathrm{a}}$ & 13.36 & 2,42 & $<0.01$ \\
$\mathrm{Be}$ & $0.80 \pm 0.10^{\mathrm{a}}$ & $0.00 \pm 0.00^{\mathrm{b}}$ & $0.71 \pm 0.10^{\mathrm{a}}$ & $\mathbf{3 0 . 0 5}$ & 2 & $<0.01$ \\
$\mathrm{Co}$ & $0.14 \pm 0.02^{\mathrm{a}}$ & $0.16 \pm 0.02^{\mathrm{a}}$ & $0.13 \pm 0.02^{\mathrm{a}}$ & 0.97 & 2,42 & 0.39 \\
$\mathrm{Cr}$ & $1.58 \pm 0.11^{\mathrm{a}}$ & $2.52 \pm 0.37^{\mathrm{b}}$ & $1.52 \pm 0.13^{\mathrm{a}}$ & 17.78 & 2,42 & $<0.01$ \\
$\mathrm{Cu}$ & $2.05 \pm 0.14^{\mathrm{a}}$ & $1.86 \pm 0.45^{\mathrm{a}}$ & $1.50 \pm 0.11^{\mathrm{a}}$ & 1.15 & 2,42 & 0.34 \\
$\mathrm{Fe}$ & $25.47 \pm 1.62^{\mathrm{a}}$ & $109.64 \pm 10.81^{\mathrm{b}}$ & $23.52 \pm 1.73^{\mathrm{a}}$ & $\mathbf{2 9 . 7 1}$ & 2 & $<0.01$ \\
$\mathrm{Li}$ & $0.25 \pm 0.03^{\mathrm{b}}$ & $0.11 \pm 0.04^{\mathrm{c}}$ & $0.34 \pm 0.02^{\mathrm{a}}$ & 18.35 & 2,42 & $<0.01$ \\
$\mathrm{Mn}$ & $0.60 \pm 0.03^{\mathrm{a}}$ & $1.89 \pm 0.20^{\mathrm{b}}$ & $0.51 \pm 0.04^{\mathrm{a}}$ & $\mathbf{3 1 . 3 2}$ & 2 & $<0.01$ \\
$\mathrm{Mo}$ & $0.11 \pm 0.02^{\mathrm{a}}$ & $0.12 \pm 0.04^{\mathrm{a}}$ & $0.12 \pm 0.03^{\mathrm{a}}$ & 0.02 & 2,42 & 0.98 \\
$\mathrm{Ni}$ & $0.53 \pm 0.20^{\mathrm{a}}$ & $2.43 \pm 0.53^{\mathrm{b}}$ & $0.17 \pm 0.08^{\mathrm{a}}$ & 37.74 & 2,42 & $<0.01$ \\
$\mathrm{~Pb}$ & $1.30 \pm 0.20^{\mathrm{a}}$ & $1.23 \pm 0.39^{\mathrm{a}}$ & $0.82 \pm 0.05^{\mathrm{a}}$ & 2.94 & 2,42 & 0.11 \\
$\mathrm{Sb}$ & $0.40 \pm 0.05^{\mathrm{a}}$ & $0.10 \pm 0.03^{\mathrm{b}}$ & $0.48 \pm 0.06^{\mathrm{a}}$ & 15.95 & 2,42 & $<0.01$ \\
$\mathrm{Se}$ & $0.80 \pm 0.08^{\mathrm{a}}$ & $1.72 \pm 0.14^{\mathrm{b}}$ & $1.03 \pm 0.10^{\mathrm{a}}$ & 19.78 & 2,42 & $<0.01$ \\
$\mathrm{Sn}$ & $0.43 \pm 0.04^{\mathrm{a}}$ & $1.92 \pm 0.41^{\mathrm{b}}$ & $0.55 \pm 0.05^{\mathrm{a}}$ & $\mathbf{3 0 . 2 2}$ & 2 & $<0.01$ \\
$\mathrm{Sr}$ & $1.61 \pm 0.11^{\mathrm{a}}$ & $2.28 \pm 0.21^{\mathrm{b}}$ & $1.49 \pm 0.09^{\mathrm{a}}$ & $\mathbf{1 1 . 4 4}$ & 2 & $<0.01$ \\
$\mathrm{Ti}$ & $5.53 \pm 0.15^{\mathrm{a}}$ & $9.30 \pm 0.71^{\mathrm{b}}$ & $6.05 \pm 0.16^{\mathrm{a}}$ & $\mathbf{2 1 . 5 0}$ & 2 & $<0.01$ \\
$\mathrm{~V}$ & $1.24 \pm 0.04^{\mathrm{a}}$ & $0.12 \pm 0.06^{\mathrm{b}}$ & $1.19 \pm 0.05^{\mathrm{a}}$ & 148.26 & 2,42 & $<0.01$ \\
$\mathrm{Zn}$ & $46.25 \pm 1.62^{\mathrm{a}}$ & $77.01 \pm 3.57^{\mathrm{b}}$ & $48.60 \pm 2.21^{\mathrm{a}}$ & $\mathbf{2 6 . 0 2}$ & 2 & $<0.01$ \\
& & & & & & \\
\hline
\end{tabular}

fish species, feed used, culturing period, and RAS-operational characteristics (Martins et al. 2011). However, several researchers reported the accumulation of certain elements such as $\mathrm{Cu}$ in RAS, and much more attention should be paid to these elements (Deviller et al. 2005, Davidson et al. 2009, 2011, Martins et al. 2009).

Arsenic, categorized as a toxic element, is harmful to humans (Qin et al. 2015). In the present study, RAS fish had an As level of $1.18 \mu \mathrm{g} \mathrm{g}^{-1}$, which was not significantly different from that in CP fish (Duncan's multiple comparison test, $\mathrm{p}=0.12$; Table 2). However, As was found to accumulate in fish cultured in RAS in previous studies. Arsenic accumulation impaired larval development in the common carp Cyprinus carpio (Martins et al. 2009). When Nile tilapia Oreochromis niloticus were cultured in RAS tanks with 3 different element, is potentially toxic to fish in acidified waters (Abdel Ghani 2015). RAS can accumulate carbon dioxide and have a lower $\mathrm{pH}$ when the water exchange rate is decreased. Attention should be paid to Al toxicity even at low concentrations when the $\mathrm{pH}$ is below 6.2 in RAS water because of the increase of solubility of $\mathrm{Al}$ at lower $\mathrm{pH}$ (Blancheton et al. 2007). In another study, sea bass Dicentrarchus labrax had a significantly higher muscle concentration of As, Cr, $\mathrm{Co}, \mathrm{Cu}, \mathrm{Mn}, \mathrm{Ni}$, and $\mathrm{Ti}$ in fish reared in RAS compared with fish from a flow-through system (Deviller et al. 2005). An additional RAS study (Martins et al. 2009) also reported higher concentrations of $\mathrm{As}, \mathrm{Cu}$, $\mathrm{Mn}, \mathrm{Ni}$, and $\mathrm{Zn}$ in RAS water with a low water exchange rate (30 $\mathrm{l} \mathrm{kg}^{-1}$ feed $\mathrm{d}^{-1}$ ) when compared to RAS water with a high water exchange rate (1500 l $\mathrm{kg}^{-1}$ feed $\mathrm{d}^{-1}$ ). A further study by Davidson et al. (2009) on rainbow trout reported that 9 out of 28 tested elements ( $\mathrm{B}, \mathrm{Cu}, \mathrm{Li}, \mathrm{Mg}, \mathrm{P}, \mathrm{K}, \mathrm{Na}, \mathrm{S}$, and $\mathrm{Zn}$ ) were significantly higher in trout cultured in RAS with low system water flushing rate compared to trout in RAS with higher system water flushing rate, though only $\mathrm{Cu}$ reached chronically toxic levels. The differences in the reported mineral concentrations by different researchers are likely due to elemental accumulation being affected by many factors, such as water exchange rates, the fish from the RAS with a lower water exchange rate had a muscle As level of 2.88 to $11.2 \mathrm{\mu g} \mathrm{g}^{-1}$ dry weight as well as As accumulation in the liver (Martins et al. 2011). Finally, the As concentration in sea bass Dicentrarchus labrax reared in RAS was $9.8 \mu \mathrm{g} \mathrm{g}^{-1}$, which was significantly higher than that in fish cultured in a flow-through system (Deviller et al. 2005). Attention should therefore be paid to the accumulation of As in RAS as a precautionary measure.

\section{Source and uptake of trace elements in aquaculture systems}

The main sources of trace elements in aquaculture systems with reduced water exchange rate are metals added to the feed as part of the mineral premix and elements leaching from pipes and fittings (Colt 2006). Trace elements are usually added to commercial diets in the form of premixes to avoid mineral deficiencies in fish. The part of the feed that is not eaten by the fish will stay in the culture and re-use water in an RAS, resulting in the accumulation of certain trace elements such as $\mathrm{As}, \mathrm{Cu}, \mathrm{Mn}, \mathrm{Ni}$, and $\mathrm{Zn}$ (Martins et al. 2009, van Bussel et al. 2014). 
The feed used in the present study had high concentrations of $\mathrm{Al}, \mathrm{Fe}$, and $\mathrm{Zn}$ (from 100 to $800 \mathrm{\mu g} \mathrm{g}^{-1}$ dry weight), followed by $\mathrm{Cr}, \mathrm{Mn}$, and $\operatorname{Sr}\left(>10 \mu \mathrm{g} \mathrm{g}^{-1}\right)$, As, Ba, Co, Cu, Li, Ni, Pb, Se, and Ti $\left(>1 \mu g^{-1}\right)$ and comparatively low concentrations of $\mathrm{Be}, \mathrm{Mo}, \mathrm{Sb}, \mathrm{Sn}$, and $\mathrm{V}$ (Table 3). $\mathrm{Zn}, \mathrm{Mn}$, and $\mathrm{Cu}$ are added to eel feed in large quantities as they are essential trace elements for eel (89-183, 32-40, and 8.4-10.5 $\mu \mathrm{g} \mathrm{g}^{-1}$, respectively; Yamashita et al. 2006). Those values reflect the concentrations found in the feed used in the present study (Table 3). Other elements, which are not essential for eel, are contaminants present in the fishmeal and starch components of the feed (Yamashita et al. 2006).

Mineral concentrations are extremely variable in fish feeds, as illustrated e.g. by the ranges of elements found in 38 commercial fish feeds in Europe (all per g dry weight): Fe (148-247 $\mu \mathrm{g} \mathrm{g}^{-1}$ ), Zn $\left(80-636 \mu \mathrm{g} \mathrm{g}^{-1}\right), \mathrm{Mn}\left(39-184 \mu \mathrm{g} \mathrm{g}^{-1}\right), \mathrm{Cu}(11-54 \mu \mathrm{g}$ $\left.\mathrm{g}^{-1}\right), \mathrm{Pb}\left(0.9-4.9 \mu \mathrm{g} \mathrm{g}{ }^{-1}\right)$, Co $\left(2.8-4.6 \mu \mathrm{g} \mathrm{g}{ }^{-1}\right)$, Ni (1.0-4.2 $\left.\mu \mathrm{g} \mathrm{g} \mathrm{g}^{-1}\right), \mathrm{Cr}\left(1.4-3.0 \mu \mathrm{g} \mathrm{g}^{-1}\right)$, and $\mathrm{Cd}$ (0.18-0.34 $\mu \mathrm{g} \mathrm{g}^{-1}$ ) (Tacon \& Silva 1983). There are many reasons for this variation, including differences in raw ingredients, the addition of specific macro- or

Table 3. Mean $( \pm \mathrm{SE})$ concentration ( $\mu \mathrm{g} \mathrm{g}^{-1}$ dry weight) of 20 trace elements in commercial feed used for marbled eel Anguilla marmorata in this study (measured in triplicate) and commercial feeds for 2 other fish species (rainbow trout Oncorhynchus mykiss feed data from Fallah et al. 2011; haddock Melanogrammus aeglefinus feed data from Roy \& Lall 2006). (-) data not available

\begin{tabular}{|lrcc|}
\hline Element & \multicolumn{1}{c}{$\begin{array}{c}\text { Marbled eel } \\
\text { feed }\end{array}$} & $\begin{array}{c}\text { Rainbow trout } \\
\text { feed }\end{array}$ & $\begin{array}{c}\text { Haddock } \\
\text { feed }\end{array}$ \\
\hline $\mathrm{Al}$ & $210.88 \pm 5.07$ & - & $4.10 \pm 0.23$ \\
$\mathrm{As}$ & $3.10 \pm 0.33$ & $1.15 \pm 0.36$ & $0.21 \pm 0.12$ \\
$\mathrm{Ba}$ & $3.46 \pm 0.08$ & $3.49 \pm 0.56$ & $5.50 \pm 0.41$ \\
$\mathrm{Be}$ & $0.04 \pm 0.01$ & - & - \\
$\mathrm{Co}$ & $1.78 \pm 0.07$ & $1.00 \pm 0.24$ & $2.01 \pm 0.04$ \\
$\mathrm{Cr}$ & $10.76 \pm 0.61$ & $0.98 \pm 0.24$ & $0.34 \pm 0.12$ \\
$\mathrm{Cu}$ & $7.581 \pm 0.66$ & $7.37 \pm 0.94$ & $5.18 \pm 0.91$ \\
$\mathrm{Fe}$ & $760.2 \pm 6.60$ & $48.63 \pm 4.68$ & $450 \pm 30$ \\
$\mathrm{Li}$ & $2.78 \pm 0.15$ & - & - \\
$\mathrm{Mn}$ & $41.25 \pm 0.28$ & $18.73 \pm 2.02$ & $130 \pm 20$ \\
$\mathrm{Mo}$ & $0.94 \pm 0.06$ & $0.38 \pm 0.12$ & $0.30 \pm 0.04$ \\
$\mathrm{Ni}$ & $5.65 \pm 0.30$ & $0.95 \pm 0.27$ & - \\
$\mathrm{Pb}$ & $1.61 \pm 0.21$ & $2.41 \pm 0.41$ & - \\
$\mathrm{Sb}$ & $0.26 \pm 0.34$ & - & - \\
$\mathrm{Se}$ & $2.32 \pm 0.59$ & $3.39 \pm 0.65$ & - \\
$\mathrm{Sn}$ & $0.96 \pm 0.10$ & - & - \\
$\mathrm{Sr}$ & $94.42 \pm 1.65$ & $4.74 \pm 0.68$ & $32.20 \pm 5.32$ \\
$\mathrm{Ti}$ & $8.6 \pm 0.30$ & - & - \\
$\mathrm{V}$ & $0.09 \pm 0.09$ & - & - \\
$\mathrm{Zn}$ & $119.94 \pm 0.96$ & $37.06 \pm 3.52$ & $314.21 \pm 5.21$ \\
& & & \\
\hline
\end{tabular}

trace-mineral premixes, and contaminants present in raw ingredients (Tacon \& Silva 1983). The large variation in mineral composition in commercial fish feeds might result in the accumulation of different trace elements in fish cultured in RAS systems. Mineral compositions of commercial feed for rainbow trout and haddock differ from that in eel feed (Table 3). Notably, the Fe concentrations in the feed of eel and haddock are much higher than that in rainbow trout feed (Table 3), so it is not surprising that the corresponding $\mathrm{Fe}$ concentrations in the fish themselves follow the same pattern (Table 4). The Sr concentration in the eel feed is higher than that in the haddock and rainbow trout feeds; however, the Sr concentration in the eel itself is lower than that in the haddock and rainbow trout (Table 4). This pattern might be caused by factors other than the Sr concentration in the feed, such as water quality, fish behavior, or metabolic activity (Yi \& Zhang 2012). The Al concentration in the eel feed $\left(210.88 \mu \mathrm{g} \mathrm{g}^{-1}\right)$ used in the present study was much higher than the $\mathrm{Al}$ concentration in the feeds for other previously reported studies on haddock (4.1 $\mathrm{g} \mathrm{g} \mathrm{g}^{-1}$, Table 3), channel catfish (75 $\mu \mathrm{g}$ $\mathrm{g}^{-1}$ dry weight; Li et al. 2015) and Nile tilapia (71.2 $\mu \mathrm{g}$ $\mathrm{g}^{-1}$ dry weight; Martins et al. 2011). The feed was therefore likely the reason for the high Al concentration in the eels in our low-water-exchange systems (RAS and BFT) when compared to CP fish (Table 2).

Fish bioaccumulate metals from the ambient habitat either from the water or from the feed (Kalantzi et al. 2013). Metals mainly exist in the water in the form of free metal ions, ion pairs, chelates, or hydrolysis products. Concentrations of free metal ions are usually rather low in most of the culture water (Boyd 2000). For instance, $\mathrm{Cu}^{2+}$ only accounts for a small portion of the inorganic copper in water, and most copper occurs in complex forms (Boyd 2000). Almost all the complex copper is in the form of $\mathrm{CuCO}_{3}$ and when the $\mathrm{pH}$ value is kept constant, the concentration of $\mathrm{Cu}^{2+}$ does not change as the alkalinity increases in the water, but the concentration of $\mathrm{CuCO}_{3}$ will increase (Boyd 2000). The alkalinity of the source water in the present study was $280 \mathrm{mg} \mathrm{l}^{-1} \mathrm{CaCO}_{3}$, which is relatively high compared to most freshwater sources, so the proportion of $\mathrm{CuCO}_{3}$ was likely also high in this type of water. $\mathrm{Cu}^{2+}, \mathrm{CuOH}^{+}$, and $\mathrm{CuCO}_{3}$ are the main forms of copper taken up by the gills or the intestinal epithelium of fish (Grosell et al. 2004); therefore, gill uptake was probably an important process of $\mathrm{Cu}$ absorption by Anguilla marmorata in the present study. For other trace elements, gill uptake by fish may be low because of the form that the elements are present in water. For example, $\mathrm{Fe}^{2+}$ is more 
Table 4. Mean $( \pm \mathrm{SE})$ and range of concentration ( $\mu \mathrm{g} \mathrm{g}^{-1}$ dry weight) of 20 trace elements in the muscle of marbled eel Anguilla marmorata reared in a recirculating aquaculture system (RAS) in the present study and 2 other fish species (rainbow trout Oncorhynchus mykiss from a race-way system, data from Fallah et al. 2011; haddock Melanogrammus aeglefinus from a flow-through system, data from Roy \& Lall 2006). (-) data not available

\begin{tabular}{|lccc|}
\hline \multirow{2}{*}{ Element } & Marbled eel & Rainbow trout & Haddock \\
\hline $\mathrm{Al}$ & $19.36 \pm 2.42(8.05-42.81)$ & - & $5.40 \pm 1.07$ \\
$\mathrm{As}$ & $1.18 \pm 0.09(0.60-1.79)$ & $0.93 \pm 0.29(0.00-2.39)$ & $3.20 \pm 1.10$ \\
$\mathrm{Ba}$ & $1.02 \pm 0.11(0.70-2.12)$ & $1.80 \pm 0.34(0.21-3.40)$ & $1.94 \pm 0.09$ \\
$\mathrm{Be}$ & $0.80 \pm 0.10(0.31-1.30)$ & - & - \\
$\mathrm{Co}$ & $0.14 \pm 0.02(0.01-0.25)$ & $0.19 \pm 0.0(0.00-0.50)$ & $0.12 \pm 0.04$ \\
$\mathrm{Cr}$ & $1.58 \pm 0.11(1.09-2.51)$ & $0.57 \pm 0.15(0.00-1.59)$ & $0.68 \pm 0.22$ \\
$\mathrm{Cu}$ & $2.05 \pm 0.14(1.46-3.36)$ & $21.81 \pm 2.7(7.48-39.90)$ & $3.84 \pm 0.32$ \\
$\mathrm{Fe}$ & $25.47 \pm 1.62(16.12-40.71)$ & $15.47 \pm 3.13(3.23-39.87)$ & $25.06 \pm 2.22$ \\
$\mathrm{Li}$ & $0.25 \pm 0.03(0.08-0.46)$ & - & - \\
$\mathrm{Mn}$ & $0.60 \pm 0.03(0.37-0.82)$ & $6.26 \pm 0.89(2.13-12.99)$ & $2.84 \pm 0.26$ \\
$\mathrm{Mo}$ & $0.11 \pm 0.02(0.00-0.19)$ & $0.11 \pm 0.04(0.00-0.37)$ & $0.23 \pm 0.02$ \\
$\mathrm{Ni}$ & $0.53 \pm 0.20(0.03-1.09)$ & $0.38 \pm 0.11(0.00-1.00)$ & - \\
$\mathrm{Pb}$ & $1.30 \pm 0.20(0.48-3.79)$ & $1.11 \pm 0.40(0.00-4.45)$ & - \\
$\mathrm{Sb}$ & $0.40 \pm 0.05(0.00-0.16)$ & - & - \\
$\mathrm{Se}$ & $0.80 \pm 0.08(0.29-1.61)$ & $2.05 \pm 0.51(0.00-4.86)$ & - \\
$\mathrm{Sn}$ & $0.43 \pm 0.04(0.13-0.67)$ & - & - \\
$\mathrm{Sr}$ & $1.61 \pm 0.11(1.16-2.32)$ & $3.62 \pm 0.61(1.07-6.98)$ & $12.30 \pm 3.23$ \\
$\mathrm{Ti}$ & $5.53 \pm 0.15(4.88-6.77)$ & - & - \\
$\mathrm{V}$ & $1.24 \pm 0.04(0.87-1.48)$ & - & - \\
$\mathrm{Zn}$ & $46.25 \pm 1.62(36.06-57.39)$ & $20.97 \pm 4.42(6.74-59.09)$ & $33.20 \pm 1.44$ \\
& & & \\
\hline
\end{tabular}

\section{Comparing the mineral concentration in A. marmorata with other fish species}

When comparing the trace element concentrations among A. marmorata reared in an RAS (present study) and 2 other species farmed in systems with high water-exchange rate, A. marmorata had higher concentrations of $\mathrm{As}, \mathrm{Cr}, \mathrm{Fe}, \mathrm{Ni}, \mathrm{Pb}$, and Zn than rainbow trout Oncorhynchus mykiss cultured in a race-way system (Table 4). A. marmorata also had much higher concentrations of $\mathrm{Al}, \mathrm{Cr}$, and $\mathrm{Zn}$ than haddock that were farmed in a flow-through system (Table 4). Yamashita et al. (2006) measured the concentrations of 5 elements that were also evaluated in the present study (As, Cu, $\mathrm{Mn}, \mathrm{Zn}$, and Se) in wild or farmraised Japanese eel A. japonica in 5 regions in Asia and reported the following ranges: 0.04-0.92 $\mu \mathrm{g}$ As $\mathrm{g}^{-1}, 0.1-0.2 \mu \mathrm{g} \mathrm{Cu} \mathrm{g}{ }^{-1}, 0.06-0.25 \mu \mathrm{g}$ readily available than $\mathrm{Fe}^{3+}$, but in oxygenated water, $\mathrm{Fe}^{2+}$ can be oxidized to $\mathrm{Fe}^{3+}$. Although iron uptakes by gills of freshwater fish are greater than by marine fish, diet is the most important source of iron in both environments (Bury \& Grosell 2003).

In BFT systems, water is usually not changed because carbohydrates are added to the system to promote the growth of heterotrophic bacteria. The heterotrophic bacteria could assimilate toxic ammonia-nitrogen into bacterial biomass, which is subsequently eaten by the fish, resulting in nutrient recycling (De Schryver et al. 2008). Most of the studies related to BFT systems have focused on the dynamics of inorganic elements such as carbon and nitrogen (e.g. Kamilya et al. 2017). The mechanism of trace element uptake in this type of system is therefore not yet clear. Therefore, further studies should be conducted to investigate the bio-availability of trace elements, mechanisms of aqueous uptake of trace elements by cultured species, and cross-effects of accumulation of several minerals in a BFT system. Moreover, though the trace element concentrations in tilapia Oreochromis niloticus and water spinach Ipomoea aquatica Forsk were not measured in this study, there may be additional trace element accumulation in these 2 species and this can be investigated further.
$\mathrm{Mn} \mathrm{g}^{-1}$, 9.0-15.3 $\mu \mathrm{g} \mathrm{Zn} \mathrm{g}^{-1}$, and 0.14-0.26 $\mu \mathrm{g} \mathrm{Se} \mathrm{g}^{-1}$. By comparison, the $\mathrm{Cu}$ and $\mathrm{Zn}$ concentrations were much higher in the present study (Table 4). Overall, A. marmorata cultured in RAS in the present study have higher levels of several trace elements compared with those reported previously for other fish species.

The concentrations of trace elements in A. marmorata were compared with Chinese national food safety levels (Ministry of Health of People's Republic of China 2005). For comparison purposes, the wet weight concentration of a trace element given in the regulations was converted to dry weight using a wet weight to dry weight conversion factor of 4 (Onsanit et al. 2010, Hao et al. 2013). The Ministry of Health of People's Republic of China (2005) only sets maximum allowable residue limits in fish for 4 of the trace elements we tested, namely $\mathrm{Pb}\left(2 \mu \mathrm{g} \mathrm{g}^{-1}\right.$ dry weight), $\mathrm{Cr}$ (8 $\mu \mathrm{g} \mathrm{g}^{-1}$ dry weight), As ( $2 \mu \mathrm{g} \mathrm{g}^{-1}$ dry weight), and Se ( $4 \mu \mathrm{g} \mathrm{g}^{-1}$ dry weight). None of the fish in the present study exceeded the maximum allowable residue limits except for As in fish from the BFT system, with a level of $2.06 \mu \mathrm{g} \mathrm{g}^{-1}$ dry weight. The European Commission has considered a much stricter upper limit for $\mathrm{Pb}$ (1.2 $\mu \mathrm{g} \mathrm{g}^{-1}$ dry weight, EU 2006). The fish we reared in the RAS and BFT culture systems slightly exceeded this European limit (Table 2). 


\section{CONCLUSIONS}

This study investigated the concentrations of 20 trace elements in Anguilla marmorata reared in 3 different aquaculture systems. Fish cultured in RAS tended to accumulate more $\mathrm{Al}$ compared with fish reared in a traditional $\mathrm{CP}$, possibly because of the high $\mathrm{Al}$ concentration in the eel feed in combination with the low water exchange rate of the RAS. A. marmorata cultured in polyculture with tilapia Oreochromis niloticus and water spinach Ipomoea aquatica in the BFT system had significantly higher concentrations of 11 trace elements (As, Ba, Cr, Fe, $\mathrm{Mn}, \mathrm{Ni}, \mathrm{Se}, \mathrm{Sn}, \mathrm{Sr}, \mathrm{Ti}$, and $\mathrm{Zn}$ ) compared to fish cultured in CPs or RASs. Regular monitoring of trace element concentrations in BFT and RAS systems should be implemented in the future, because the levels of (1) As in fish from BFT systems and (2) Pb in fish from both RAS and BFT systems exceeded national and international legislatory limits. The water exchange rate should be increased if trace element accumulation is detected.

Acknowledgements. This study was funded by the National Natural Science Foundation of China (No. 31402317), the Scientific Research Foundation for the Returned Overseas Chinese Scholars, the State Education Ministry, and the Fundamental Research Funds for the Central Universities (grant number 201612006). We thank Dr. Liping Liu and Dr. Zaizhong Chen from Shanghai Ocean University for providing the fish samples. We thank Dr. Yangen Zhou from Auburn University for his useful comments about the manuscript.

\section{LITERATURE CITED}

Abdel Ghani SA (2015) Trace metals in seawater, sediments and some fish species from Marsa Matrouh Beaches in north-western Mediterranean coast, Egypt. Egypt J Aquat Res 41:145-154

Avnimelech Y, Kochba M (2009) Evaluation of nitrogen uptake and excretion by tilapia in bio floc tanks, using ${ }^{15} \mathrm{~N}$ tracing. Aquaculture 287:163-168

Bakar NSA, Nasir NM, Lananan F, Hamid SHA, Su SL, Jusoh A (2015) Optimization of $\mathrm{C} / \mathrm{N}$ ratios for nutrient removal in aquaculture system culturing African catfish, (Clarias gariepinus) utilizing Bioflocs Technology. Int Biodeterior Biodegradation 102:100-106

Blancheton JP, Piedrahita R, Eding EH, D'Orbcastel ER, Lemarié G, Bergheim A, Fivelstad S (2007) Intensification of land based aquaculture production in single pass and reuse systems. In: Bergheim A (ed) Aquacultural engineering and environment. Research Signpost, Kerala, p 21-47

Boyd CE (2000) Water quality: an introduction. Kluwer Academic Publishers, Boston, MA

Bury N, Grosell M (2003) Iron acquisition by teleost fish. Comp Biochem Physiol C Toxicol Pharmacol 135:97-105
Ministry of Health of People's Republic of China (2005) National food safety standard: maximum levels of contaminants in food. GB 2762-2005 (in Chinese). https:// wenku.baidu.com/view/da38bc1e6bd97f192279e932.html

Colt J (2006) Water quality requirements for reuse systems. Aquacult Eng 34:143-156

* Crab R, Avnimelech Y, Defoirdt T, Bossier P, Verstraete W (2007) Nitrogen removal techniques in aquaculture for a sustainable production. Aquaculture 270:1-14

C Crab R, Defoirdt T, Bossier P, Verstraete W (2012) Biofloc technology in aquaculture: beneficial effects and future challenges. Aquaculture 356-357:351-356

* Davidson J, Good C, Welsh C, Brazil B, Summerfelt S (2009) Heavy metal and waste metabolite accumulation and their potential effect on rainbow trout performance in a replicated water reuse system operated at low or high system flushing rates. Aquacult Eng 41:136-145

WDavidson J, Good C, Welsh C, Summerfelt ST (2011) Abnormal swimming behavior and increased deformities in rainbow trout Oncorhynchus mykiss cultured in low exchange water recirculating aquaculture systems. Aquacult Eng 45:109-117

* De Schryver P, Crab R, Defoirdt T, Boon N, Verstraete W (2008) The basics of bio-flocs technology: the added value for aquaculture. Aquaculture 277:125-137

* Deviller G, Palluel O, Aliaume C, Asanthi H and others (2005) Impact assessment of various rearing systems on fish health using multibiomarker response and metal accumulation. Ecotoxicol Environ Saf 61:89-97

EU (2006) Commission Regulation (EC) No 1881/2006 of 19 December 2006 setting maximum levels for certain contaminants in foodstuffs. Off J Eur Union L 49:5-24. http:// eur-lex.europa.eu/legal-content/EN/TXT/?uri=OJ:L:2006: 364:TOC

Fallah AA, Saei-Dehkordi SS, Nematollahi A, Jafari T (2011) Comparative study of heavy metal and trace element accumulation in edible tissues of farmed and wild rainbow trout (Oncorhynchus mykiss) using ICP-OES technique. Microchem J 98:275-279

Grosell M, Mcdonald MD, Walsh PJ, Wood CM (2004) Effects of prolonged copper exposure in the marine gulf toadfish (Opsanus beta) II: copper accumulation, drinking rate and $\mathrm{Na}^{+} / \mathrm{K}^{+}$-ATPase activity in osmoregulatory tissues. Aquat Toxicol 68:263-275

*Hao Y, Chen L, Zhang X, Zhang D, Zhang X, Yu Y, Fu J (2013) Trace elements in fish from Taihu Lake, China: levels, associated risks, and trophic transfer. Ecotoxicol Environ Saf 90:89-97

Kalantzi I, Black KD, Pergantis SA, Shimmield TM, Papageorgiou N, Sevastou K, Karakassis I (2013) Metals and other elements in tissues of wild fish from fish farms and comparison with farmed species in sites with oxic and anoxic sediments. Food Chem 141:680-694

Kamilya D, Debbarma M, Pal P, Kheti B, Sarkar S, Singh ST (2017) Biofloc technology application in indoor culture of Labeo rohita (Hamilton, 1822) fingerlings: the effects on inorganic nitrogen control, growth and immunity. Chemosphere 182:8-14

* Lee CS, Li X, Shi W, Cheung SC, Thornton I (2006) Metal contamination in urban, suburban, and country park soils of Hong Kong: a study based on GIS and multivariate statistics. Sci Total Environ 356:45-61

Li L, Boyd CE, Dong S (2015) Chemical profiling with modeling differentiates Ictalurid catfish produced in fertilized and feeding ponds. Food Control 50:18-22 
Luo M, Guan R, Li Z, Jin H (2013) The effects of water temperature on the survival, feeding, and growth of the juveniles of $A$. marmorata and A. bicolor pacifica. Aquaculture 400-401:61-64

Luo G, Gao Q, Wang C, Liu W, Sun D, Li L, Tan H (2014) Growth, digestive activity, welfare, and partial costeffectiveness of genetically improved farmed tilapia (Oreochromis niloticus) cultured in a recirculating aquaculture system and an indoor biofloc system. Aquaculture 422-423:1-7

Martins CIM, Pistrin MG, Ende SSW, Eding EH, Verreth JAJ (2009) The accumulation of substances in Recirculating Aquaculture Systems (RAS) affects embryonic and larval development in common carp Cyprinus carpio. Aquaculture 291:65-73

Martins CIM, Eding EH, Verreth JAJ (2011) The effect of recirculating aquaculture systems on the concentrations of heavy metals in culture water and tissues of Nile tilapia Oreochromis niloticus. Food Chem 126: 1001-1005

Mendil D, Uluözlü ÖD (2007) Determination of trace metal levels in sediment and five fish species from lakes in Tokat, Turkey. Food Chem 101:739-745

Mendil D, Uluözlü ÖD, Hasdemir E, Tüzen M, Sari H, Suiçmez M (2005) Determination of trace metal levels in seven fish species in lakes in Tokat, Turkey. Food Chem 90:175-179

Mendil D, Ünal ÖF, Tüzen M, Soylak M (2010) Determination of trace metals in different fish species and sediments from the River Yeşilırmak in Tokat, Turkey. Food Chem Toxicol 48:1383-1392

Editorial responsibility: Chris Noble,

Tromsø, Norway
Onsanit S, Ke C, Wang X, Wang KJ, Wang WX (2010) Trace elements in two marine fish cultured in fish cages in Fujian province, China. Environ Pollut 158:1334-1342

* Qin D, Jiang H, Bai S, Tang S, Mou Z (2015) Determination of 28 trace elements in three farmed cyprinid fish species from Northeast China. Food Control 50:1-8

* Rahman MM, Nagelkerke LAJ, Verdegem MCJ, Wahab MA, Verreth JAJ (2008) Relationships among water quality, food resources, fish diet and fish growth in polyculture ponds: a multivariate approach. Aquaculture 275: 108-115

* Roy PK, Lall SP (2006) Mineral nutrition of haddock Melanogrammus aeglefinus (L.): a comparison of wild and cultured stock. J Fish Biol 68:1460-1472

* Tacon AGJ, Silva SSD (1983) Mineral composition of some commercial fish feeds available in Europe. Aquaculture 31:11-20

*van Bussel CGJ, Schroeder JP, Mahlmann L, Schulz C (2014) Aquatic accumulation of dietary metals (Fe, Zn, $\mathrm{Cu}, \mathrm{Co}, \mathrm{Mn}$ ) in recirculating aquaculture systems (RAS) changes body composition but not performance and health of juvenile turbot (Psetta maxima). Aquacult Eng 61:35-42

*Yamashita Y, Omura Y, Okazaki E (2006) Distinct regional profiles of trace element content in muscle of Japanese eel Anguilla japonica from Japan, Taiwan, and China. Fish Sci 72:1109-1113

*Yi YJ, Zhang SH (2012) The relationships between fish heavy metal concentrations and fish size in the upper and middle reach of Yangtze River. Procedia Environ Sci 13:1699-1707

Submitted: March 15, 2017; Accepted: November 8, 2017

Proofs received from author(s): January 18, 2018 